\title{
Immunodominance of a Low-Affinity Major Histocompatibility Complex-binding Myelin Basic Protein Epitope (Residues 111-129) in HLA-DR4 (B1*0401) Subjects Is Associated with a Restricted T Cell Receptor Repertoire
}

\author{
Paolo A. Muraro, ${ }^{\star \S}$ Marco Vergelli, ${ }^{*}$ Matthias Kalbus, Darhlene E. Banks, ${ }^{\star}$ James W. Nagle, ${ }^{\ddagger}$ Laura R. Tranquill, ${ }^{\star}$ \\ Gerald T. Nepom," William E. Biddison, ${ }^{*}$ Henry F. McFarland, ${ }^{*}$ and Roland Martin ${ }^{\star}$ \\ $*$ Neuroimmunology Branch, and ${ }^{\ddagger}$ DNA Sequencing Facility, National Institute of Neurological Disorders and Stroke, National Institutes \\ of Health, Bethesda, Maryland 20892-1400; §Department of Oncology and Neuroscience, Medical School, University "G. D'Annunzio," \\ Chieti 66100 Italy; "Department of Neurology, Medical School, University of Tübingen, 72076 Germany; and "Virginia Mason Research \\ Center, Seattle, Washington 98101
}

\begin{abstract}
The pathogenesis of multiple sclerosis (MS) is currently ascribed in part to a $\mathrm{T}$ cell-mediated process targeting myelin components. The $\mathrm{T}$ cell response to one candidate autoantigen, myelin basic protein (MBP), in the context of HLA-DR15Dw2, has been previously studied in detail. However, the characteristics of cellular immunity in the context of other MS-associated HLA-DR haplotypes are scarcely known. MBP-specific T cell lines (TCL) were generated from HLA-DR4 (B1*0401)-positive MS subjects. Out of 275 MBP-specific TCL, 178 (64.7\%) specifically recognized region $\mathrm{MBP}(111-129)$, predominantly in the context of DRB1*0401. The major T cell epitope for MBP recognition corresponded to residues MBP(116-123). These TCL expressed disparate profiles of cytokine secretion and cytotoxicity. $T$ cell receptor analysis, on the other hand, revealed a strikingly limited heterogeneity of rearrangements. In contrast to $\mathrm{MBP}(81-99)$, which binds with high affinity to HLA-DR15 and is recognized by a diverse $T$ cell repertoire, MBP(111-129) binds weakly to DRB1*0401, suggesting that only high affinity $T$ cell receptors might be able to efficiently engage such unstable MHC/peptide complexes, thus accounting for the $T$ cell receptor restriction we observed. This study provides new insight about MBP recognition and proposes an alternative mechanism for immunodominance of self-antigen $\mathrm{T}$ cell epitopes in humans. (J. Clin. Invest. 1997. 100:339-349.) Key words: multiple sclerosis • autoimmune diseases • CD4-positive T lymphocytes • autoantigens • complementarity-determining region
\end{abstract}

\section{Introduction}

Myelin basic protein (MBP) $)^{1}$ is the most intensively studied candidate target antigen in multiple sclerosis (MS) (1). Characterization of the human $\mathrm{T}$ cell response to MBP has defined

This work was presented in part at the 48th meeting of the American Academy of Neurology, March 1996 and has appeared in abstract form (1996. Neurology. 46[Suppl.]: A436-A437).

Address correspondence to Paolo A. Muraro, Neuroimmunology Branch, National Institute of Neurological Disorders and Stroke, National Institutes of Health, Building 10, Room 5B-16, 10 Center Drive MSC 1400, Bethesda, MD 20892-1400. Phone: 301-402-4488; FAX: 301-402-0373; E-mail: pmuraro@box-p.nih.gov

Received for publication 7 November 1996 and accepted in revised form 15 April 1997.

The Journal of Clinical Investigation

Volume 100, Number 2, July 1997, 339-349 three major immunodominant regions, located in the $\mathrm{NH}_{2}$-terminal (1-19), central (87-106, 84-102, 87-99), and COOH-terminal (143-168, 131-159) domains (2-7). However, other studies reported the recognition of several $\mathrm{T}$ cell epitopes in the context of various HLA restriction elements, indicating a higher degree of complexity (8-12). Despite these discrepancies, the central T cell epitope cluster of $\operatorname{MBP}(87-99)$, recognized in the context of MS-associated HLA-DR molecules, in particular DR15, has undergone intense investigation, with the intention of exploring its therapeutic potential. The identification of peptides with altered T cell receptor (TCR) or MHC contact residues might provide the opportunity of modulating the immune response to $\mathrm{MBP}$, as suggested by observations in the animal model experimental allergic encephalomyelitis (EAE) $(13,14)$.

It is unlikely, however, that those treatments might benefit patients with other immunogenetic backgrounds. In fact, very little information is currently available on the immune response to myelin antigens in subjects carrying other HLA class II haplotypes such as DR4, which has been described in association with MS in different ethnic groups (15-18). The recognition of different immunodominant regions of a protein antigen may correlate with different MHC restriction molecules. This possibility might account for the diversity observed in studies that included groups of individuals expressing various HLA haplotypes. According to this concept, selection of a given HLA haplotype as defined by molecular typing should allow a more thorough dissection of the $\mathrm{T}$ cell response to myelin antigens.

This study examines the characteristics of the $\mathrm{T}$ cell response to MBP in MS patients and normal subjects carrying the HLA-DR4 (B1*0401) allele. We have generated MBPspecific $\mathrm{T}$ cell lines (TCL) to estimate the frequency of autoreactive cells and examine their characteristics with respect to fine epitope recognition, HLA restriction, cytotoxicity, profile of cytokine production, and TCR usage. This allowed us to identify a clearly immunodominant MBP epitope cluster. Interestingly and in contrast to the T cell response to $\mathrm{MBP}(81-$ $99)$ in the context of HLA-DRB1*1501/B5*0101, we have found a remarkably restricted set of TCR rearrangements in TCL recognizing $\mathrm{MBP}(111-129)$ in the context of DRB1* 0401. Potential reasons that explain the immunodominance of this MBP epitope are discussed.

1. Abbreviations used in this paper: AMCA, 7-amino-4-methylcoumarin-3 acetic acid; APC, antigen presenting cell; CM, complete medium; EAE, experimental allergic encephalomyelitis; IMDM, Iscove's modified Dulbecco's medium; MBP, myelin basic protein; MS, multiple sclerosis; TCL, T cell line; TCR, T cell receptor; Th, T helper. 


\section{Methods}

Subjects. Candidate donors were typed for HLA-class II by standardized molecular typing methods by the Department of Transfusion Medicine, National Institutes of Health (NIH, Bethesda, MD). Designations of HLA types are given according to the WHO Nomenclature Committee (19). Six MS patients and six age- and gendermatched healthy subjects, all carrying the HLA-DRB1*0401 allele, were selected for this study. The study was reviewed and approved by the Institute Clinical Research Subpanel, and informed consent was obtained from each patient. The mean age of MS patients (five females, one male) was $41.1 \pm 8.2 \mathrm{yr}$. The mean age of normal controls (five females, one male) was $40.1 \pm 13.3 \mathrm{yr}(P=0.886)$. No subject had received steroid or immunosuppressive therapy within 6 mo of blood sampling. Duration of disease, clinical course and complete HLA haplotypes are reported in Table I.

Antigens. Human MBP was prepared according to the method of Deibler (20). Peptides were synthesized on a peptide synthesizer (990; Beckman Instruments, Fullerton, CA) using Merrifield solid phase synthesis methodology. The crude peptide product after desalting was then purified by CM-32 carboxymethylcellulose cation-exchange chromatography to $>95 \%$ purity (21). The synthetic product was characterized by amino acid analysis, mass spectrometry, and reversephase HPLC. Some peptides [MBP(112- to 119-129) and MBP(111121 to -128$)$ ] were synthesized using t-Boc chemistry and a tea bag methodology as described (22), HPLC-purified and analyzed for purity and identity as above. Sequences of MBP peptides were: MBP(119), ASQKRPSQRHGSKYLATAS; (11-29), GSKYLATASTMDHARHGFL; (21-39), MDHARHGFLPRHRDTGILD; (31-49), RHRDTGILDSLGRFFGGDR; (41-59), LGRFFGGDRGAPKRGSGKD; (51-69), APKRGSGKDSHHAARTTHY; (61-79), HHAARTTHYGSLPQKSHGR; (71-89), SLPQKSHGRTQDENPVVHF; (81-99), QDENPVVHFFKNIVTPRTP; (91-109), KNIVTPRTPPPSQGKGRGL; (101-119), PSQGKGRGLSLSRFSWGAE; (111-129), LSRFSWGAEGQRPGFGYGG; (121-139), QRPGFGYGGRASDYKSAHK; (131-149), ASDYKSAHKGLKGVDAQGT; (141-159), LKGVDAQGTLSKIFKLGGR; (151-170), SKIFKLGGRDSRSGSPMARR.

Generation of MBP-specific T cell lines. PBLs were isolated from leukapheresis samples by lymphocyte separation medium (Organon Teknika, Durham, NC). MBP-specific TCL were established using a modified limiting dilution technique as previously described (3).
Peripheral blood lymphocytes were seeded at $2 \times 10^{5}$ cells/well in U-bottom 96-well microtiter plates (Nunc, Roskilde, Denmark) in $200 \mu$ l Iscove's modified Dulbecco's medium (IMDM) (Gibco BRL, Grand Island, NY) containing $2 \mathrm{mM}$ L-glutamine, $100 \mathrm{U} / \mathrm{ml}$ penicillin/ streptomycin, $50 \mu \mathrm{g} / \mathrm{ml}$ gentamycin (Whittaker Bioproducts, Gaithersburg, MD), supplemented with $10 \%$ heat-inactivated pooled human serum (complete medium, $C M$ ), in the presence of $10 \mu \mathrm{g} / \mathrm{ml} \mathrm{hu-}$ man MBP. A minimum of 300 wells were seeded for each individual. Whenever possible, cultures were prepared from cells obtained at two or more time points. On day 7, $10 \mathrm{IU} / \mathrm{ml}$ human IL-2 (Lymphocult-T HP; Biotest, Dreichenhein, Germany) was added to the culture. After another 7-10 days, cells were washed within the wells and resuspended in $200 \mu \mathrm{l} \mathrm{CM.} 50 \mu \mathrm{l}$ of the cell suspension were transferred into two adjacent wells of a separate plate, and $150 \mu \mathrm{l}$ of $\mathrm{CM}$ containing $1 \times 10^{5}$ autologous irradiated (3,000 Rad) PBL as antigen presenting cells (APCs) were added to the wells. One well was stimulated with $10 \mu \mathrm{g} / \mathrm{ml} \mathrm{MBP}$. The original plates were restimulated with $1 \times 10^{5}$ autologous irradiated PBL and $10 \mu \mathrm{g} / \mathrm{ml} \mathrm{MBP}$ in the presence of $10 \mathrm{IU} / \mathrm{ml} \mathrm{IL}-2$. After $3 \mathrm{~d},\left[{ }^{3} \mathrm{H}\right]$ thymidine (Dupont, Wilmington, $\mathrm{DE}$ ) incorporation during the final $6 \mathrm{~h}$ of incubation was measured in a scintillation counter (Betaplate; Pharmacia, Gaithersburg, MD). Wells that showed a stimulation index $(\mathrm{SI})>2$ over background with a $\Delta \mathrm{cpm}>1,000$ in the proliferation assay were expanded in culture by weekly restimulation with MBP and APC, and further characterized with respect to fine specificity, HLA restriction, cytotoxicity, cytokine production, and TCR usage.

TCL characterization. Peptide specificity of the TCL was screened using a panel of 16, 19-mers that overlap by 9 amino acids and span the entire MBP sequence in standard proliferation assays, in duplicates, or triplicates. Epitopes within the immunodominant region of MBP(111-129) were mapped using a set of 16 peptides truncated at the amino (112- to 119-129) and carboxyl (111-121 to -128) termini, as antigens in proliferation assays. TCL were tested at least twice in duplicate wells with the panel of truncated peptides. Equimolar concentrations of these peptides were used, ranging from $10^{-3}$ to $10^{2} \mu \mathrm{M}$. HLA-class II restriction was determined using autologous or allogeneic irradiated $(10,000 \mathrm{Rad})$ or mitomycin-C treated EBV-transformed B cells or homozygous typing cells (HTC; No. 9025, 9058, 9063, 9082, 9084) from the Tenth International Histocompatibility Workshop as APCs in proliferation assays. Alternatively, BLS-1 transfectants were used to present peptide antigens in proliferation or cytotoxicity assays. These cells were generated by transfection of DR

Table I. Characteristics of Subjects

\begin{tabular}{|c|c|c|c|c|c|c|c|}
\hline Initials & Sex & Age & Disease duration & Course ${ }^{\ddagger}$ & HLA-DRB1* & HLA-DQB1* & HLA-DRB3,4,5* \\
\hline & & & $y r$ & & & & \\
\hline \multicolumn{8}{|c|}{ Multiple sclerosis patients } \\
\hline MS1 & $\mathrm{F}$ & 37 & 6 & $\mathrm{R} / \mathrm{R}$ & 0401,0701 & $02 *, 0302$ & $\mathrm{~B} 4 * 01 *$ \\
\hline MS2 & $\mathrm{F}$ & 27 & 5 & $\mathrm{CP}$ & 1302,0401 & $0301,06^{*}$ & $\mathrm{~B} 3 * 0301, \mathrm{~B} 4 * 0101$ \\
\hline MS3 & $\mathrm{F}$ & 49 & 9 & $\mathrm{RP}$ & 0401,0701 & 0201,0301 & $\mathrm{~B} 4 * 0101$ \\
\hline MS4 & $\mathrm{F}$ & 43 & 13 & $\mathrm{CP}$ & 0401,0701 & $03 *, 02 *$ & $\mathrm{~B} 4 * 01$ \\
\hline MS5 & $\mathrm{M}$ & 48 & 12 & $\mathrm{CP}$ & 1501,0401 & $05 *-06 *, 03 * \S$ & $\mathrm{B} 4 * 01 *$ \\
\hline MS6 & $\mathrm{F}$ & 43 & 20 & $\mathrm{CP}$ & 0401,1301 & $03 *, 0603$ & B3*0202,B4*0101 \\
\hline \multicolumn{8}{|c|}{ Healthy donors } \\
\hline HD1 & $\mathrm{F}$ & 27 & - & - & 0401,0701 & 0201,0302 & $\mathrm{~B} 4 * 0101$ \\
\hline HD2 & $\mathrm{F}$ & 55 & - & - & 0401,1302 & 0302,0604 & $\mathrm{~B} 3 * 0301, \mathrm{~B} 4 * 0101$ \\
\hline HD3 & $\mathrm{F}$ & 58 & - & - & 0401,1501 & 0301,0602 & $\mathrm{~B} 4 * 0101, \mathrm{~B} 5 * 0101$ \\
\hline HD4 & $\mathrm{M}$ & 34 & - & - & 0401,1501 & 0301,0602 & B4*0101,B5*0101 \\
\hline HD5 & $\mathrm{F}$ & 38 & - & - & 0401 & 0301 & B4*0101 \\
\hline HD5 & $\mathrm{F}$ & 29 & - & - & 0101,0401 & 0501,0301 & $\mathrm{~B} 4 * 0101$ \\
\hline
\end{tabular}

${ }^{\ddagger} \mathrm{R} / \mathrm{R}$, relapsing/remitting; $\mathrm{CP}$, chronic progressive; RP, relapsing/progressive. ${ }^{\S}$ Determined by serological typing and listed according to the correspondent molecular nomenclature. 
molecules into a class II-null cell line (BLS-1) by a retrovirus-mediated gene transfer system, as described (23). This allowed us to confirm antigen presentation specifically in the context of the selected DR allele. Antigen-dependent cytotoxicity was studied by means of standard ${ }^{51} \mathrm{Cr}$ release assays performed in triplicate wells with effector/target ratios ranging from 1:1 to 20:1, as described (3). Cytokine secretion was measured in culture supernatants obtained $48 \mathrm{~h}$ after stimulation of T cells $\left(2 \times 10^{5}\right)$ with APCs $\left(1 \times 10^{6}\right)$ in the presence or absence of antigen $(10 \mu \mathrm{g} / \mathrm{ml})$, using solid phase ELISA assays (Biosource, Camarillo, CA). Background values were subtracted from those of Ag-stimulated cultures. To assess TCL T helper (Th) profile, IFN- $\gamma$, TNF- $\alpha$, and TNF- $\beta$ were measured as markers of Th1like T cells. IL-4 was regarded as the distinctive cytokine of Th2-like cells. Additionally, IL-10 secretion was measured. TCL showing an IFN- $\gamma /$ IL-4 ratio $>10$ were considered Th1-like; those that had a ratio $>0.1$ and $<10$ were regarded as Th0; those showing a ratio of 0.1 or less were counted as Th2-like. RNA was isolated by a modified guanidinium-isothiocyanate method (24) and reverse-transcribed into cDNA using oligo(dT) and random hexanucleotide primers (First-Strand cDNA synthesis kit; Pharmacia LKB Biotechnology, Uppsala, Sweden). TCR variable chain usage was analyzed by PCR using a panel of $21 \mathrm{~V} \alpha$ and $22 \mathrm{~V} \beta$ family-specific oligonucleotide primers essentially as described (25). Each set of reactions included a

Table II. Predominant Response to MBP(111-129) within $M B P$-specific TCL

\begin{tabular}{|c|c|c|c|c|}
\hline \multirow{2}{*}{$\begin{array}{c}\text { Subject } \\
\text { (time point) }\end{array}$} & \multicolumn{2}{|c|}{ MBP-reactive TCLs* } & \multicolumn{2}{|c|}{$\begin{array}{l}\text { MBP(111-129)- } \\
\text { specific TCL }\end{array}$} \\
\hline & No. positive & $\%$ positive & No. positive & $\%$ positive \\
\hline \multicolumn{5}{|l|}{ MS patients } \\
\hline MS1 & $18 / 480$ & 3.8 & $8 / 9$ & 88.9 \\
\hline \multicolumn{5}{|l|}{ MS2 } \\
\hline 1988 & $13 / 288$ & 4.5 & $12 / 13$ & 92.3 \\
\hline 1995 & $8 / 192$ & 4.2 & $4 / 5$ & 80.0 \\
\hline \multicolumn{5}{|l|}{ MS3 } \\
\hline 1988 & $16 / 288$ & 5.6 & $2 / 4$ & 50.0 \\
\hline 1995 & $41 / 480$ & 8.5 & $3 / 6$ & 50.0 \\
\hline MS4 & $34 / 300$ & 11.3 & $20 / 34$ & 58.8 \\
\hline MS5 & $24 / 480$ & 5.0 & $3 / 12$ & 25.0 \\
\hline MS6 & $15 / 360$ & 4.2 & $6 / 15$ & 40.0 \\
\hline \multicolumn{5}{|c|}{ Healthy donors } \\
\hline HD1 & $161 / 480$ & 33.5 & $2 / 12$ & 16.7 \\
\hline HD2 & $24 / 480$ & 5.0 & $23 / 24$ & 95.8 \\
\hline HD3 & $13 / 480$ & 2.7 & $2 / 4$ & 50.0 \\
\hline \multicolumn{5}{|l|}{ HD4 } \\
\hline 1991 & $28 / 96$ & 29.2 & $5 / 5$ & 100.0 \\
\hline 1993 (i) & $213 / 480$ & 44.4 & $23 / 23$ & 100.0 \\
\hline 1993 (ii) & $17 / 96$ & 17.7 & $4 / 4$ & 100.0 \\
\hline 1994 & $10 / 96$ & 10.4 & $5 / 6$ & 83.3 \\
\hline HD5 & $47 / 564$ & 8.3 & $26 / 47$ & 55.3 \\
\hline HD6 & $56 / 510$ & 11.0 & $31 / 56$ & 55.4 \\
\hline Total & $755 / 6150$ & 12.3 & $178 / 275$ & 64.7 \\
\hline
\end{tabular}

*MBP-specific TCL were established from PBL $\left(2 \times 10^{5} /\right.$ well $)$ stimulated with $10 \mu \mathrm{g} / \mathrm{ml} \mathrm{MBP}$. Results of the proliferation of primary cultures (MBP-reactive TCL) are given as (No. of responding wells)/(No. of seeded wells). ${ }^{*}$ Numbers indicate the proportion of MBP(111-129) among MBP-specific TCL which were tested for fine specificity. The majority responded to peptide $\mathrm{MBP}(111-129)$ only; the percentages of TCL recognizing other specificities are given in the Results section. positive control for the amplification of TCR constant region to monitor the quality of the template and the efficiency of the reaction. Special care was taken to avoid cross-contamination of PCR samples. Separately amplified, purified PCR products containing an EcoRI restriction site were ligated into pUC18 EcoRI/BAP plasmid vector (Pharmacia LKB Biotechnology), and used to transform Escherichia coli JM109 competent cells (Stratagene, Inc., La Jolla, CA), according to the specifications of the manufacturer. Multiple bacterial colonies were screened for the presence of the recombinant TCR fragment. Sequencing was carried out from purified plasmid DNA using the Sanger-dideoxy chain termination method and Sequenase (U.S. Biotechnology, Cleveland, OH). At least two colonies for each TCR rearrangement were sequenced on both strands. Alternatively, direct sequencing of PCR products was performed using ABI Prism ${ }^{\text {TM }}$ DyeTerminators (Applied Biosystems, Inc., Foster City, CA) according to the manufacturer's recommendations. Sequencing reactions were analyzed on an Applied Biosystems 373A automated DNA sequencer. The primers used included forward TCRAV/TCRBV family-specific primers and reverse generic primers annealing in the $5^{\prime}$ end of the TCR $\alpha$ or $\beta$ constant region. Sequencing results were analyzed using GCG software (26), and compared with published TCR gene segments (27-29). Complementarity determining region 3 (CDR3) was defined according to the criteria of Rock et al. (30). TCR designations are given accordingly to the current guidelines of the WHOIUIS Nomenclature Subcommittee (31).

High performance size exclusion chromatography peptide binding assay. $\mathrm{NH}_{2}$-terminal labeling of peptides with the fluorescent dye, 7-amino-4-methylcoumarin-3 acetic acid (AMCA) (Calbiochem, San Diego, CA) was performed as previously described (32). Peptide binding to affinity-purified DRB1*0401 was measured by high performance size exclusion chromatography as described (33). Competitor peptides $(4 \mu \mathrm{g})$ were used in 20 -fold molar excess $(58 \mu \mathrm{M})$ relative to the high affinity-DRB1*0401-binding peptide AMCA-HA (307-319) (2.9 $\mu \mathrm{M})$. Relative competition was calculated from fluorescence signals in the absence $\left(\mathrm{F}_{0}\right)$ and the presence $\left(\mathrm{F}_{\mathrm{c}}\right)$ of competitor: \% competition $=\left(\mathrm{F}_{0}-\mathrm{F}_{\mathrm{c}}\right) \times \mathrm{F}_{0}{ }^{-1} \times 100$.

Statistical analysis. When appropriate, a two-tailed unpaired Student's $t$ test was used to analyze differences between groups. Frequency of MBP responding cells was calculated by dividing the number of responding wells in the screening proliferation assays by the number of wells seeded, multiplied by the number of cells/well. Peptide specific-TCL frequencies are obtained by extrapolation, based on their relative proportion in the subsequent specificity analysis, as previously described (5).

\section{Results}

MBP(111-129) dominates the HLA-DRB1*0401-restricted T cell response. Frequency and fine specificity. Out of a total of 6,150 wells seeded from PBL obtained from 12 subjects, 755 $(12.3 \%)$ responded to $\mathrm{MBP}$ in the proliferation assay with a stimulation index $>2$ (Table II). The individual response to MBP ranged from 2.7 to $44.4 \%$ (estimated frequency, $1.35 \times$ $10^{-7}$ to $2.21 \times 10^{-6}$ ). The percentage of MBP-positive wells was higher in healthy donors $(18.0 \pm 17.9 \%)$ than in MS patients $(6.2 \pm 3.0 \%)$, yet this difference was not statistically significant. A proliferative response to MBP was confirmed in 307 out of 351 wells which were positive in the initial proliferation screening (specificity $=87.5 \%) .178$ out of $275(64.7 \%)$ MBP-specific TCL which were tested for fine specificity responded to peptide MBP(111-129) (Table II). The proportion of MBP(111-129)-specific TCL among all the MBP-specific ones did not differ significantly in MS patients $(59.2 \%)$ and healthy controls $(66.9 \%)$. Other than to MBP(111-129), we found TCL responding specifically to the majority of MBP peptides; among those, 1-19 (3.9\%), 71-89 (3.9\%), 81-99 


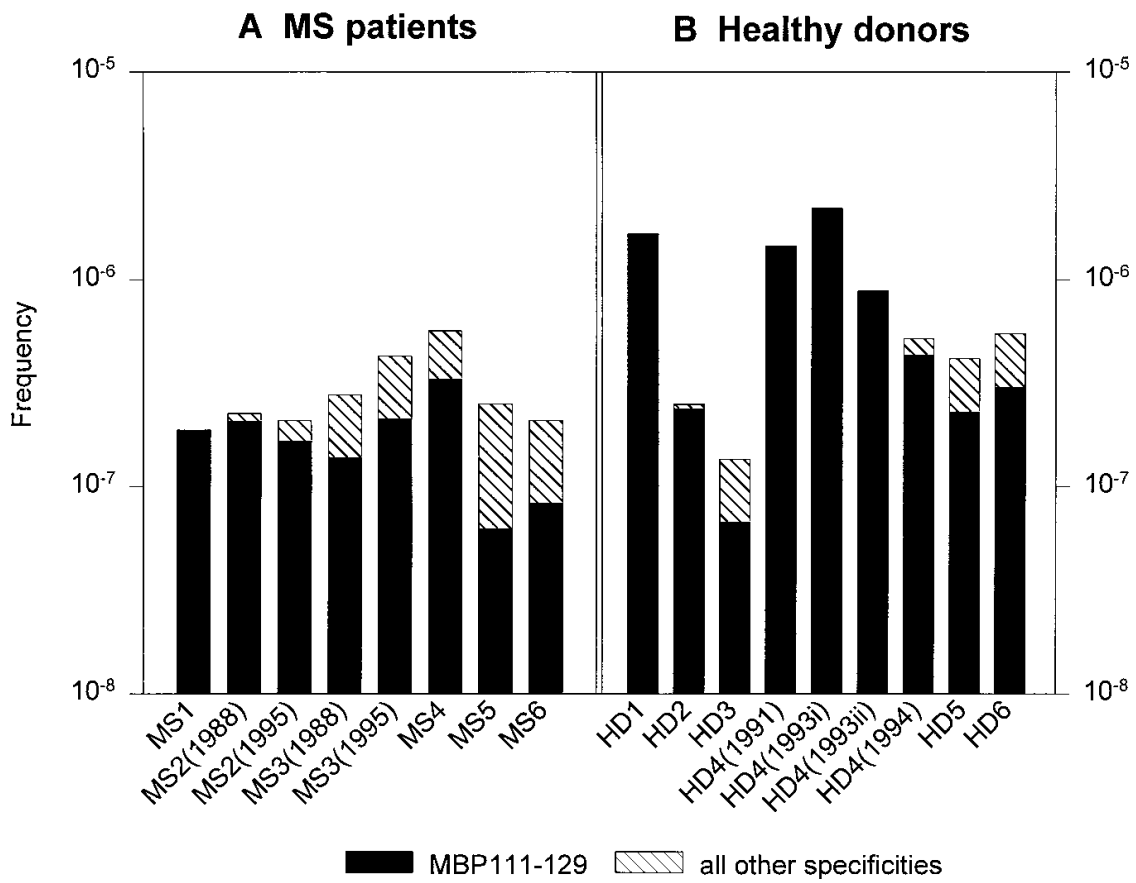

Figure 1. Estimated precursor frequency in MS patients $(A)$ and normal controls $(B)$. Frequency of MBP-specific T cells (whole bars) and relative frequencies of TCL specific for MBP(111-129) (solid segments) and for all other MBP peptides (dashed segments) are shown. Frequencies of MBP-responding cells are calculated dividing the number of responding wells by the number of wells seeded, multiplied by the number of cells/well. Peptide specific-TCL frequencies are extrapolated based on their relative proportion, as described (5). In the majority of subjects, MBP(111-129)specific TCL are clearly predominant even over all other cumulated specificities. The difference in average frequency of normal subjects and patients is not statistically significant, in part due to interindividual variability within the healthy donors group.
(6.6\%), and 131-149 (2.6\%) were the most frequent. We did not observe TCL specific for MBP(21-39), (31-49), and (151$170)$, suggesting that $\mathrm{T}$ cell epitopes of those MBP regions are either not represented, or essential residues in those regions extend across the overlaps between adjacent peptides of our set. The estimated relative frequencies of MBP-reactive and MBP(111-129)-specific T cells are shown in Fig. 1. Depending on growth and availability of autologous cells, TCL were ex-
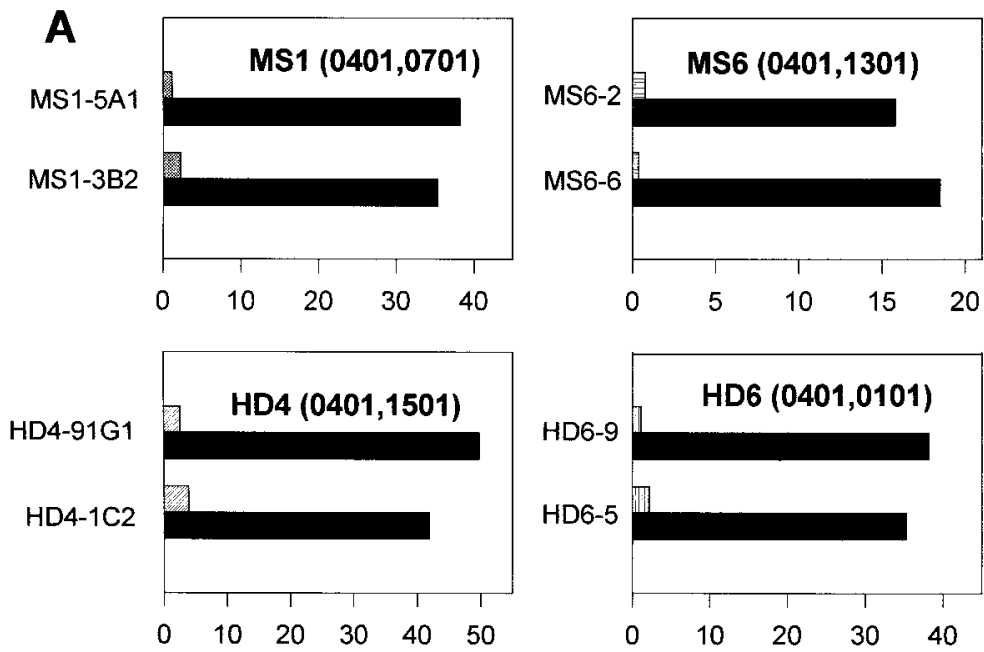

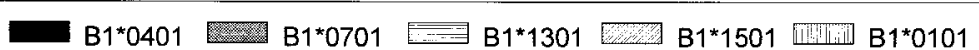

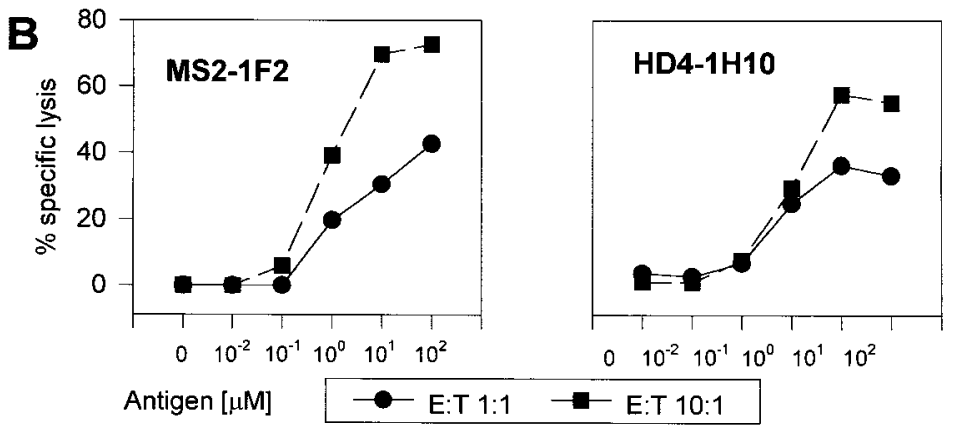

Figure 2. Examples of HLA-DRB1*0401-restricted proliferative $(A)$ and cytotoxic $(B) \mathrm{T}$ cell response. $(A)$ Mitomycin-C-treated transfected B cells expressing the indicated HLA-DR specificities were used in proliferation assays as APCs to present MBP(111-129) to TCL. Results show the HLA-DRB1*0401-restricted proliferative response of 2 representative TCL/subject. Results are given in stimulation indices (S.I.) over control (no antigen prepulse) APCs. Details about the HLA-DR restriction analysis are given in the text. (B) Examples of cytotoxic TCL recognizing antigen specifically presented in the context of DRB $1 * 0401$ by BLS-1.Dw4 transferent cells, pulsed with different concentrations of peptide MBP(111-129). Two effector/target $(E: T)$ ratios were used in dose/response experiments such as those shown. Non cytotoxic, weakly cytotoxic, and highly cytotoxic T cells are present among MBP(111-129)-specific TCL (see Table IV). Different grades of cytotoxicity can be observed in TCL with the same specificity originated from individual donors. 
Table III. Fine Epitope Recognition of MBP(111-129)-responding TCL

\begin{tabular}{lc}
\hline \multicolumn{1}{c}{ TCL } & Minimal epitope* \\
\hline MS1-3B2 & SWGAEGQRPG \\
MS1-5A1 & WGAEGQRP \\
MS2-1B3 & SWGAEGQRP \\
MS2-1F2 & WGAEGQRP \\
MS2-3C8 & WGAEGQRP \\
MS2-3E5 & WGAEGQRP \\
MS3-1D1 & SWGAEGQRP \\
MS3-2 & WGAEGQRP \\
MS3-11 & WGAEGQRP \\
MS5-2F6 & WGAEGQRP \\
MS5-4D1 & WGAEGQRPGF \\
HD1-14 & WGAEGQRP \\
HD3-5E9 & WGAEGQRP \\
HD3-5H2 & WGAEGQRP \\
HD4-1C2 & WGAEGQRPGE \\
HD4-91G1 & WGAEGQRPGF \\
HD4-94H3 & WGAEGQRPGF \\
\end{tabular}

* The shortest epitope recognized by each MBP(111-129)-reactive TCL was assessed by proliferation assays using a set of 16 peptides truncated at the amino and carboxyl termini (see Fig. 3). Each TCL was tested twice or more.

panded in culture by restimulation every 7-10 d and characterized. HLA-restriction was determined in $61 \mathrm{MBP}$-specific TCL. All TCL were found to be restricted by HLA-DR molecules. 38 out of 40 (95\%) TCL specific for MBP(111-129) were restricted by B1*0401 (Fig. 2). The remaining 2 TCL (5\%) of that group were B1*0701 restricted. Among the TCL with other specificities, a less skewed distribution was found. Out of
21 TCL tested, 9 were B1*0401 restricted (43\%), and 12 were restricted by the other allele product (57\%). A total of 38 HLA-DRB1*0401-restricted TCL specific for MBP(111-129) were characterized in further detail. To dissect $\mathrm{T}$ cell epitope recognition of peptide $\mathrm{MBP}(111-129)$, we used a set of peptides truncated at the amino and carboxyl termini. We first tested the truncated peptides in a wide range of concentrations $\left(10^{-2}\right.$ to $\left.10^{3} \mu \mathrm{M}\right)$ in dose/response proliferation assays (data not shown). At the optimal antigen concentration of $10 \mu \mathrm{M}$, the minimum epitope length was readily determined in a representative sample of TCL (Table III). The major $\mathrm{T}$ cell epitope identified corresponds to MBP residues 116-123 (Fig. 3 ). Interestingly, a corresponding epitope has been described for encephalitogenic T cells in animal models $(13,34)$.

MBP(111-129)-specific TCL have heterogeneous functional characteristics. Study of TCL phenotype included antigen-specific cytotoxicity and cytokine secretion. We have used the ${ }^{51} \mathrm{Cr}$ release assay to confirm both the specific, HLA-DRrestricted Ag recognition, and to study the ability of these TCL to lyse antigen-pulsed target cells. Representative examples are shown in Fig. 2 B, and results are summarized in Table IV. Remarkably, both highly cytotoxic and noncytotoxic TCL, with the same specificity and HLA restriction, were generated from individual donors. Based on their profile of cytokine secretion, MBP(111-129)-specific TCL originating from different subjects display different T helper phenotypes (Table IV). Interestingly, several TCL originating from a healthy subject (HD4) secreted high levels of IFN- $\gamma$, TNF- $\alpha$ and no IL-4, indicating predominance of Th1-like cells. Most TCL produced moderate to high levels of IL-10. No association of any of the functional characteristics analyzed in the TCL to the presence or absence of disease was found in our study. However, a larger number of observations might be required to confirm this lack of correlation.

Low-binding affinity of the immunodominant peptide $M B P(111-129)$ to $H L A-D R B 1 * 0401$. The observation of a large
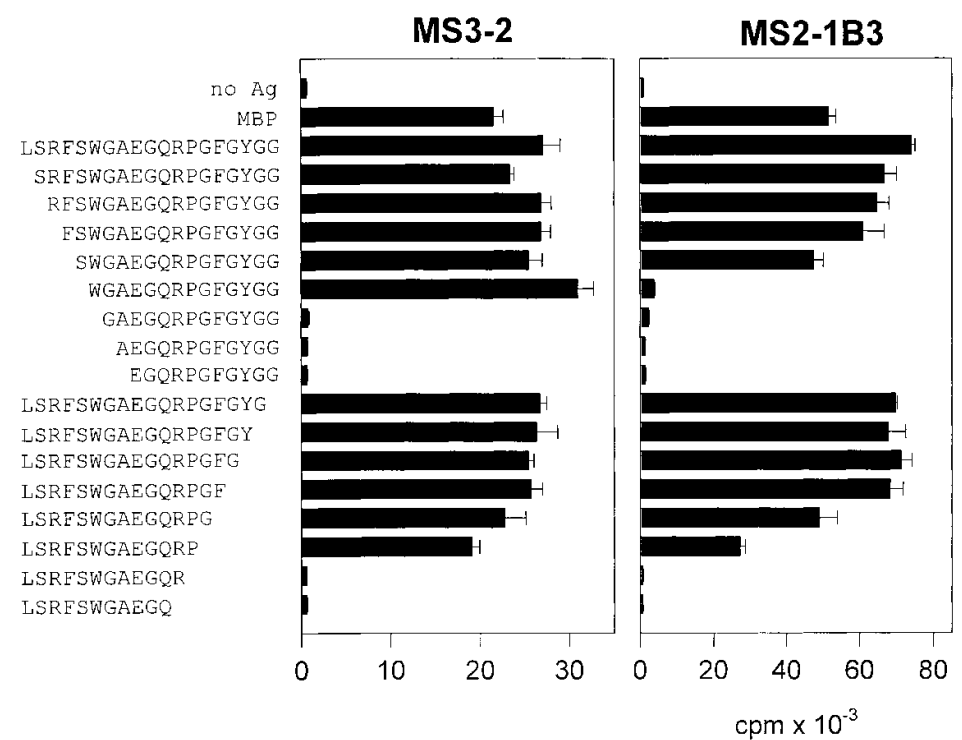

Figure 3. Distinct patterns of proliferative response of TCL recognizing two different epitopes within the MBP (111-129) domain. The use of equimolar concentrations of peptides truncated in the amino and carboxyl termini of the MBP(111-129) amino acid sequence allowed the identification of the minimal epitope length. The concentration of $10 \mu \mathrm{M}$ was the most appropriate to define $\mathrm{T}$ cell epitope boundaries. In the shown examples, truncation of S-115 abolishes proliferation of TCL MS2-1B3. Further truncation removing W-116 also abrogates proliferation of TCC MS3-2 and HD1-14. At the $\mathrm{COOH}$-terminus, elimination of P-123 drastically impairs proliferation of all TCL. Amino acid sequences are given in standard one-letter abbreviation code. 
Table IV. Cytotoxicity and Cytokine Secretion Patterns of MBP(111-129)-reactive TCL

\begin{tabular}{|c|c|c|c|c|c|c|c|c|}
\hline TCL & Cytotoxicity & IFN- $\gamma^{\ddagger}$ & TNF- $\alpha$ & TNF- $\beta$ & IL-10 & IL-4 & IFN- $\gamma /$ IL-4 ratio & Th subtypes \\
\hline \multicolumn{9}{|c|}{ MS patient derived } \\
\hline MS1-3B2 & - & 134 & 15 & 0 & 0 & 328 & 0.4 & $\mathrm{Th} 0 / \mathrm{Th} 2$ \\
\hline MS1-3C2 & - & 396 & 10 & 0 & 380 & 4838 & 0.1 & Th2 \\
\hline MS1-5A1 & - & 841 & 51 & 0 & 295 & 1619 & 0.5 & $\mathrm{Th} 0 / \mathrm{Th} 2$ \\
\hline MS2-1B3 & - & 509 & ND & 795 & 1496 & 13 & $>10.0$ & Th1 \\
\hline MS2-1F2 & +++ & 1458 & ND & 930 & 376 & 250 & 5.8 & Th0 \\
\hline MS2-3C8 & - & 2836 & 232 & 0 & 3900 & 476 & 6.0 & Th0 \\
\hline MS2-3E5 & - & 1472 & 28 & 0 & 2244 & 336 & 4.3 & Th0 \\
\hline MS3-1D1 & ++ & 2480 & 919 & 315 & 1007 & 997 & 2.5 & Th0 \\
\hline MS3-1 & + & 364 & 1182 & 935 & 1033 & 1000 & 0.4 & Th0/Th2 \\
\hline MS3-2 & +++ & 326 & 863 & 335 & 0 & 364 & 0.9 & Th0 \\
\hline MS3-11 & +++ & 1216 & 899 & 786 & 45 & 933 & 1.3 & Th0 \\
\hline MS5-2D11 & ++ & 0 & 183 & 0 & 919 & 431 & $<0.1$ & Th2 \\
\hline MS5-2F6 & +++ & 1536 & 283 & 131 & 253 & 400 & 3.8 & Th0 \\
\hline MS5-4D1 & ++ & 1984 & 134 & 347 & 8 & 522 & 3.8 & Th0 \\
\hline \multicolumn{9}{|c|}{ Healthy donor derived } \\
\hline HD1-14 & ++ & 364 & 443 & 722 & 4 & 1034 & 0.4 & Th0/Th2 \\
\hline HD3-5E9 & - & 321 & 0 & ND & 0 & 174 & 1.8 & Th0 \\
\hline HD3-5H2 & - & 205 & 155 & 0 & 0 & 96 & 2.1 & Th0 \\
\hline HD4-1H10 & + & 1106 & 533 & 330 & 990 & 0 & $>10.0$ & Th1 \\
\hline HD4-2F1 & +++ & 492 & 0 & 0 & 127 & 0 & $>10.0$ & Th1 \\
\hline HD4-2H5 & +++ & 1508 & ND & 103 & 1132 & 0 & $>10.0$ & Th1 \\
\hline HD4-3A5 & + & 504 & ND & ND & 0 & 0 & $>10.0$ & Th1 \\
\hline HD4-3B2 & +++ & 1139 & 292 & 316 & 1251 & 0 & $>10.0$ & Th1 \\
\hline HD4-4A4 & +++ & 1171 & 251 & 413 & 0 & 0 & $>10.0$ & Th1 \\
\hline HD4-91G1 & + & 2241 & ND & 495 & 2678 & 0 & $>10.0$ & Th1 \\
\hline HD4-94H3 & ++ & 507 & ND & 229 & 2192 & 0 & $>10.0$ & Th1 \\
\hline
\end{tabular}

* Grades of cytotoxicity are defined as follows:,$- 0-25 \%$ specific lysis;,$+ 25-50 \% ;++, 50-75 \% ;+++,>75 \%$. ${ }^{*}$ Cytokine secretion was measured by ELISA. Results are in pg/ml. ${ }^{\S} \mathrm{T}$ helper profile was evaluated on the basis of IFN- $/ / \mathrm{IL}-4$ ratio, as follows: $<0.1$, Th2; 0.1-10, Th0; > 10, Th1. ND, not determined.

proportion of TCL recognizing MBP(111-129) in the context of DRB1*0401 prompted us to examine potential factors that could account for the immunodominance of this MBP region. Criteria published by Hammer and co-workers (35) indicate no proper motif for strong binding of MBP(111-129) to HLADRB1*0401. In accordance to this, direct measurement of binding to HLA-DRB1*0401 using the overlapping MBP peptides showed a low binding affinity of MBP(111-129) (Fig. 4). Competition with the influenza hemagglutinin peptide HA(307-319), known to bind very efficiently to HLADRB1*0401, provided a relative quantification of the MBP peptides binding affinity, and confirmed the effective binding to HLA-DRB1*0401 of other MBP regions such as MBP(1129), (81-99). If carefully titrated, the concentration of peptide required for half-maximal competition of the AMCA-HA(307319) (i.e., $\left.K_{\mathrm{i} 50}\right)$ was $1.5 \mu \mathrm{M}$ for $\mathrm{MBP}(81-99)$ [ $1 \times$ molar excess], whereas the $K_{\mathrm{i} 50}$ for peptide $\mathrm{MBP}(111-129)$ was $115 \mu \mathrm{M}[75 \times$ molar excess].

MBP(111-129)-reactive $T$ cells use a restricted set of TCR rearrangements. The analysis of T cell receptor $\alpha / \beta$ chain variable gene usage by the TCL was performed by PCR amplification of TCR gene transcripts by using $\mathrm{V}$ region family-specific primers. The size of the amplification products ranged from $\sim 600$ to $\sim 800 \mathrm{bp}$, as expected (not shown). The results showed a strikingly limited TCRAV/TCRBV gene usage (Table V). TCRAV4 was vastly overrepresented since in every patient studied, and in two out of three normal subjects, TCRAV4expressing T cells were found. TCRAV1, 5 and 30 were other $\mathrm{V} \alpha$ that were frequently used. Predominance of TCRBV chain usage was even more remarkable, with TCRBV2 and TCRBV7 most frequently being used. The intra- and interindividualconserved usage of $\mathrm{V}$ segments suggested oligoclonal expansions in the peripheral blood of some subjects, but also the selection of specific TCR rearrangements for the recognition of specific antigen/MHC complexes. In fact, the $\mathrm{V} \alpha / \mathrm{V} \beta$ families most frequently used by our TCL did not simply correspond to those reported to be most commonly expressed in the peripheral blood TCR repertoire $(36,37)$. To address these questions the TCR of representative samples of TCL were sequenced. 21 TCR $\alpha$ and 23 TCR $\beta$ sequences that were in frame for V-N-J-C translation, and should therefore yield functional transcripts, were obtained (Table VI). Sequence analysis demonstrated in some individuals (patients MS1, MS2, and normal donor HD4), as suggested by the PCR screening, the presence of clonally expanded $\mathrm{T}$ cell populations. Cells bearing identical sequence rearrangements were independently generated from different sampling time points, indicating their persistence at detectable levels of frequency even several years apart (patient 


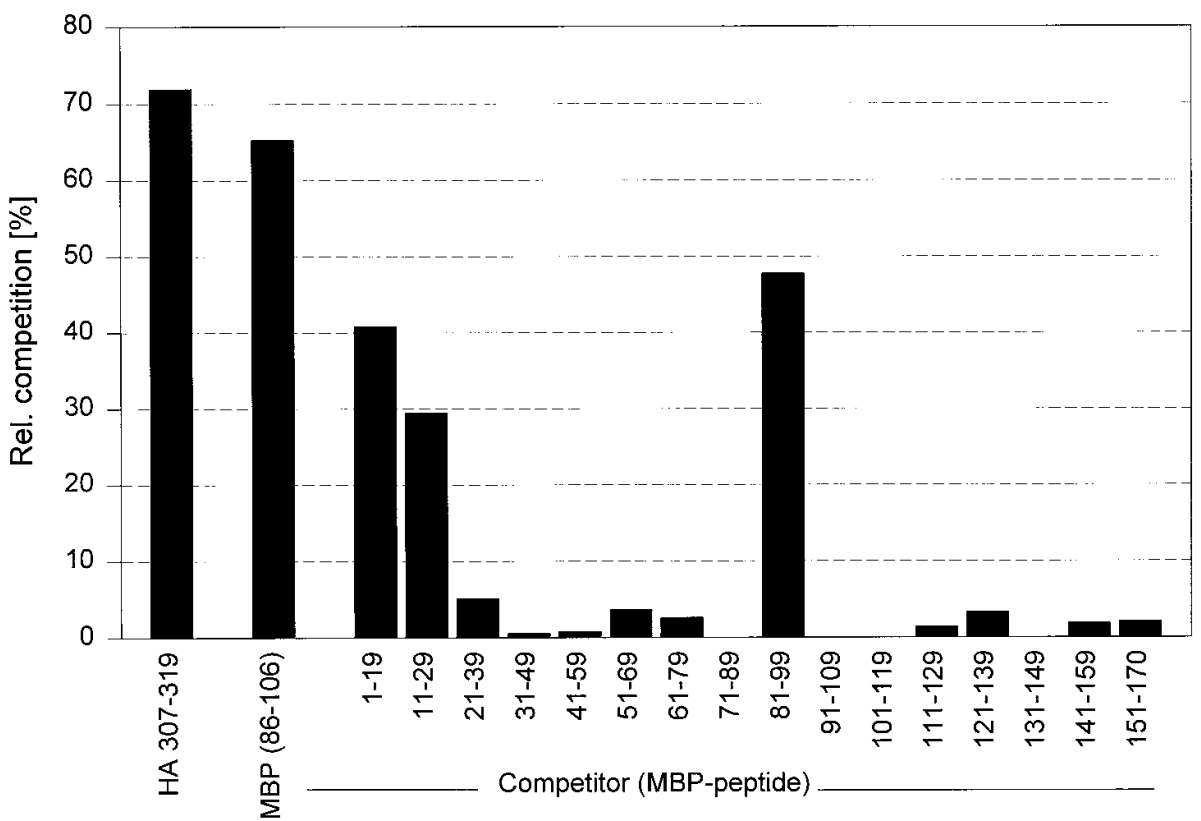

Figure 4. Competition assay: binding of AMCA-HA(307-319) to HLADRB1*0401 competition with overlapping MBP peptides (1-19) (151-170). This assay measured the ability of overlapping MBP peptides to compete with AMCA-HA(307-319) for binding to purified HLA-DRB1*0401. The capability of the amino terminal and the central (81-99) immunodominant regions of MBP to bind to several DR molecules, including DRB1*0401, was confirmed. Remarkably, the immunodominant peptide MBP(111-129) showed a low binding affinity.
MS2, healthy donor HD4). In addition, we found distinct TCR clonotypes in TCL originated from the same subject, but expressing a different phenotype (patients MS2 and MS3), which confirmed the validity of our functional data. A highly restricted junctional diversity within the CDR3 loop emerged from the analysis of the predicted amino acid sequence alignment. In particular, a valine in position $\alpha 92$ was present in $76 \%$ of the sequences ( 16 out of 21 ), followed most frequently by an arginine (28\%), a tyrosine $(28 \%)$, or a glutamine $(24 \%)$ at $\alpha 93$, and by a glycine in position $\alpha 94$ (48\%). It is noteworthy that $\alpha 92 \mathrm{Val}$ and $\alpha 93 \mathrm{Arg}$ were contributed by either the $\mathrm{N}$ addition or the $3^{\prime}$ end of the $\mathrm{V} \alpha$ region, yet conserving in any case identity and alignment. Homogeneity of CDR3 amino acid determinants was present also in $\mathrm{V} \beta$ rearrangements, presenting most frequently (87\%) a glycine in position $\beta 95(20 / 23$ sequences), followed predominantly by threonine $(35 \%)$, serine $(21 \%)$, or proline $(13 \%)$. CDR3 lengths ranged from 5 to 11 residues for the $\alpha$ chain, 7-12 for the $\beta$ chain, as calculated according to Rock et al. (30).

\section{Discussion}

Both epidemiological data and immunological observations support the concept that disease susceptibility to autoimmune diseases might be influenced by the immunogenetic background of the individual. First, putative immune disorders in humans are found in association with HLA genes, in particular HLA-DR (38). Second, in animal models for autoimmunity such as EAE, disease susceptibility of various rodent strains is under the control of MHC-class II genes (39-42). On these grounds, it is currently believed that disease-related MHC molecules may contribute to the pathogenesis by presenting specific autoantigenic peptides to T cells. In EAE, molecules encoded by MHC class II genes determine the induction of $\mathrm{T}$ cell responses to specific MBP regions. Encephalitogenic MHC class II-restricted T cell determinants have been defined in several species, and include $\mathrm{MBP}(1-9) \mathrm{NAc}$ in PL and B10.PL mice (I-A ${ }^{\mathrm{U}}$-restricted), $\mathrm{MBP}(72-84)$, and (87-99) in
Lewis rats [I-A (RT1.B) and I-E (RT1.D), respectively], at least 4 distinct epitopes in the MBP region (81-100) in SJL/J and other mice strains $\left(\mathrm{I}-\mathrm{A}^{\mathrm{s}}\right), \operatorname{MBP}(114-122,115-123)$ in guinea pig strain 13 (I-A), and MBP(110-129) in Lou/M rats $\left(\mathrm{RT}-1^{\mathrm{w}}\right)$, (reviewed in references 13 and 34). A correlation between immunodominance and encephalitogenicity has been established by these studies, and targeting the intervention on immunodominant epitopes has lead to the development of successful therapies in those experimental systems (13).

On the other hand, in outbred species such as humans, a more heterogeneous response to MBP is present, both at the level of fine epitope recognition (8-12) and T cell receptor usage (43-45), although an association of the immunodominant central epitope of $\mathrm{MBP}(87-106,81-99)$ to the DR2 haplotype has been consistently reported $(3-5,46,47)$. Approaches attempting to overcome the difficulty of the heterogeneity introduced by genes shaping the immune response to MBP in humans have included studies in siblings and twins (48-51). Those studies, although invaluable in addressing specific questions in genetically highly homogeneous subject groups, are not well suited to extrapolation to the general population. We have chosen to examine the MBP response in immunogenetically defined cohorts of unrelated MS patients and healthy subjects. In addition to the HLA-DR2 association with MS, HLA-DR4 haplotypes have been found at increased frequency in some ethnic groups, particularly in the Mediterranean area (15-18). Several DR4 subtypes have been reported associated with MS (52), including the prevalent DRB1*0401 allele, the most common DR4 subtype present in Caucasians. Interestingly, the DRB1*0401 allele is also associated with several other autoimmune diseases, including insulin-dependent diabetes mellitus $(53,54)$, rheumatoid arthritis (reviewed in reference 55), and mixed connective tissue disease (56).

In this study, we examined the T cell response to MBP in a group of DRB1*0401-positive subjects, and demonstrate a high reactivity to MBP both in MS patients and controls; this response is dominated by the response to a T cell epitope comprised within the MBP(111-129) region, presented by HLA- 
Table V. PCR Analysis of TCR Usage of

MBP(111-129)-specific TCL

\begin{tabular}{|c|c|c|}
\hline TCL & $V_{\alpha}$ & $\mathrm{V} \beta$ \\
\hline \multicolumn{3}{|l|}{ MS patients } \\
\hline MS1-3C2 & $30 *$ & 2,7 \\
\hline MS1-5A1 & $4^{\ddagger}, 30$ & 7 \\
\hline MS1-4H12 & 30 & $7(8)$ \\
\hline MS1-1A10 & 12 & 3 \\
\hline MS1-3B2 & $23 *$ & $3,6^{*}$ \\
\hline MS2-1B3 & $1(16)$ & 2 \\
\hline MS2-1F2 & $4(1)$ & 2 \\
\hline MS2-3C8 & $4(5)$ & 2 \\
\hline MS2-3E5 & $4,5^{\ddagger}$ & 2 \\
\hline MS2-951D9 & $4,5^{\ddagger}$ & $2^{*}$ \\
\hline MS2-951F3 & $4,8^{*}$ & $2, *$ \\
\hline MS3-1D1 & 8 & $8(5)$ \\
\hline MS3-1 & $30(2,4)$ & $20(3)$ \\
\hline MS3-2 & $4(2)$ & $7 *$ \\
\hline MS3-11 & $1^{*}$ & 12 \\
\hline MS5-4D1 & $4^{*}$ & $21\left(2^{\ddagger}, 5^{\ddagger \S}\right)$ \\
\hline MS5-2D11 & $23 *$ & $2^{*}$ \\
\hline MS5-2F6 & $4^{*}$ & $2\left(5^{\ddagger}, 21^{\ddagger}\right)$ \\
\hline \multicolumn{3}{|c|}{ Normal subjects } \\
\hline HD1-14 & $30,17^{\ddagger}$ & 12 \\
\hline HD3-5E9 & $4^{*}$ & $2^{\ddagger}, 6(8)$ \\
\hline HD3-5H2 & $4(18)$ & 2 \\
\hline HD4-1C2 & $4,10^{\frac{1}{2}}$ & 7 \\
\hline HD4-1H10 & 4 & 7 \\
\hline HD4-2F1 & 4 & 7,18 \\
\hline HD4-2H5 & $4(10)$ & $7 *$ \\
\hline HD4-3A5 & 4 & 7 \\
\hline HD4-3B2 & 4 & 7 \\
\hline HD4-3F12 & $4(10)$ & 7 \\
\hline HD4-4A4 & $4(10)$ & $7(8)$ \\
\hline HD4-91G1 & $4\left(10^{\ddagger}\right)$ & 7 \\
\hline HD4-91G4 & $4(5,10)$ & 7 \\
\hline HD4-94H3 & $4,10^{\ddagger}$ & $7(8)$ \\
\hline
\end{tabular}

TLC-derived cDNA was amplified by PCR using a set of TCR V $\alpha$ or $V \beta$ family specific oligonucleotide primers; products were separated by agarose gel electrophoresis and visualized by ethidium bromide staining. Minor PCR signals are in parentheses. Specificity of amplification was in most cases confirmed by DNA sequencing. *Denotes presence of additional fainter bands. ${ }^{\ddagger}$ Out of frame rearrangement. ${ }^{\S}$ TCLs MS5-4D1 and MS5-2F6 had different (out of frame) sequences, respectively, TCRBV5S7P and BV5S1A1T.

DR4(B1*0401). Previous studies comparing reactivity to MBP in MS patients and healthy controls have reported a slightly higher frequency in MS $(5,12,57)$, no significant differences $(3,4,48)$, and a trend to a higher reactivity in healthy subjects (50). Methodological differences in the establishment of TCL, in calculating the precursor frequency, and immunogenetic diversity in the populations studied might account for these discrepancies. Although we did not perform a formal frequency analysis, we observed a wide precursor frequency range in the subjects studied, together with a trend to an increased representation of MBP-specific T cells in healthy donors. However, it should be noted that the difference is probably biased by the large number of TCL generated from two young healthy donors (HD1 and HD4). These observations are compatible with the view that differences in frequency between patients and controls should not be overrated in the implication of MBPspecific T cells in the pathogenesis of MS (48). More importantly, and for the first time to our knowledge, we show that the MBP region (111-129), encompassing the encephalitogenic epitopes for guinea pig strain $13(41,58,59)$ and Lou/M rats (60), is largely immunodominant in human HLA-DRB1*0401positive individuals. MBP(111-129)-specific, mostly DRB1* 0401-restricted TCL were detectable with no exception, and contributed $>50 \%$ of all MBP-specific TCL in the majority (9/12) of subjects (Table II). Patients whose reactivity to MBP is restricted to a specific epitope cluster have been previously described $(11,61,62)$, but have generally been regarded as sporadic observations whose relevance was not fully understood. Interestingly, Vandevyver and coauthors (62) recently described a selective reactivity to peptide $\mathrm{MBP}(110-129)$ in TCL originated from three MS patients; two of them were HLA-DR $4^{+}$, the other was HLA-DR $7^{+}$. Unfortunately, since only serological typing was available, and TCL restriction to specific DR alleles was not demonstrated in that study, no conclusion can be drawn about the correspondence of those observations with the ones presently reported.

The strikingly prevalent recognition of a single MBP domain in most of the subjects we studied prompted us to investigate potential reasons which might account for this phenomenon. Mechanisms contributing to immunodominance include HLA binding, antigen proteolysis in antigen-presenting cells, and TCR usage and composition of the T cell repertoire. In mice of the $\mathrm{H}-2^{u}$ haplotype, the encephalitogenic immunodominant epitope of rat MBP, rAc1-11, forms unstable complexes with its class II restriction element, preventing the measurement of its in vitro half-life (63-65). In agreement with those observations, Joosten and co-workers, studying autoantigenic peptides from a number of self-proteins in the Lewis rat, showed that intermediate to poor binding to MHC class II RT1.B ${ }^{\mathrm{I}}$ is a property shared by most autoimmune associated peptide determinants (66). Those findings suggested that failure to promote clonal deletion in the thymus might represent a possible route for autoreactive $\mathrm{T}$ cells to escape self tolerance. Support for this hypothesis has been recently provided by the observation that in transgenic mice expressing an encephalitogenic TCR, administration of native Ac1-9 has no effect on developing $\left(\mathrm{CD}^{+} \mathrm{CD}^{+}\right)$and mature $\left(\mathrm{CD} 4^{+} \mathrm{CD} 8^{-}\right)$thymocytes, whereas peptide analogs with higher affinity for I- $\mathrm{A}^{\mathrm{u}}$ cause deletion of developing cells and TCR downregulation of mature thymocytes (67). These concepts might be relevant to the interpretation of our results in two ways. Our data show that a relatively weak MHC-binding epitope yields an immunodominant $\mathrm{CD}^{+} \mathrm{T}$ cell response, whose TCR repertoire presents specific structural constraints, both in variable gene segment usage (contributing the CDR1 and CDR2 regions) and in $\mathrm{V}$-(D)-J junctional region sequences (representing the CDR3 region). Our results parallel the observations in B10.PL and $\mathrm{PL} / \mathrm{J}$ mice (I-A ${ }^{\mathrm{u}}$ haplotype) and in the Lewis rat, in which the encephalitogenic response is restricted with respect to epitope specificity and TCR usage (68). On the other hand, they contrast the paradigm of other previously characterized MBP $\mathrm{T}$ cell epitopes that bind with high affinity to the MHC and show a more diverse TCR usage, both in humans $(45,69,70)$ and in the SJL/J (I-A $\mathrm{A}^{\mathrm{s}}$ haplotype) mouse (Martin, R., personal 
Table VI. TCR sequences of MBP(111-129)-specific TCL

\begin{tabular}{|c|c|c|c|c|c|c|c|c|c|c|}
\hline TCL & $\mathrm{TCR} \alpha$ rearrangement* & $\mathrm{V} \alpha$ & $\mathrm{N}$ & $\mathrm{J} \alpha$ & $\mathrm{C} \alpha$ & $\mathrm{TCR} \beta$ rearrangement & $\mathrm{V} \beta$ & $\mathrm{N}(\mathrm{D}) \mathrm{N}$ & $\mathrm{J} \beta$ & $\mathrm{C} \beta$ \\
\hline \multirow[t]{2}{*}{ MS2-1F2 } & AV1S1AJ31 & FCA & $\ddagger$ & VRNNARLMFGDGTQLVVKP & NIQ & $\mathrm{BV} 2 \mathrm{~S} 1 \mathrm{BJ} 2 \mathrm{~S} 2$ & CSA & SEGTSGNPTG & LFFGEGSRLTVL & EDL \\
\hline & AV4S2A2TAJ23§ & YCI & VR & IYNQGGKLIFGQGTELSVKP & NIQ & & & & & \\
\hline MS3-11 & AV1S2A1N1TAJ44 & FCAV & MH & NDMRFGAGTRLTVKP & NIQ & BV13S1BJ1S1 & CAS & RTGTGRAS & TEAFFGQGTRLTVV & EDL \\
\hline MS5-4D1 & AV1S3A2TAJ22 & FCAV & ISI & SSGSARQLTFGSGTQLTVLP & DIQ & $\mathrm{B} 21 \mathrm{~S} 2 \mathrm{~A} 2 \mathrm{BJ} 2 \mathrm{~S} 2$ & CASSL & EGTVV & TGELFFGEGSRLTVL & EDL \\
\hline MS2-3C8 & AV4S1AJ32 & $\mathrm{YC}$ & $\mathrm{TV}$ & YGGATNKLIFGTGTLLAVQP & NIQ & BV2S1BJ1S6 & CSAR & GG & SYNSPLHFGNGTRLTVT & EDL \\
\hline MS2-3E5 & AV4S1AJ32 & YC & TV & YGGATNKLIFGTGTLLAVQP & NIQ & BV2S1BJ1S6 & CSAR & GG & SYNSPLHFGNGTRLTVT & EDL \\
\hline MS2-951D9 & AV4S1AJ32 & YC & TV & YGGATNKLIFGTGTLLAVQP & NIQ & BV2S1BJ1S6 & CSAR & GG & SYNSPLHFGNGTRLTVT & EDL \\
\hline MS2-951F3 & AV4S1AJ32 & $\mathrm{YC}$ & $\mathrm{TV}$ & YGGATNKLIFGTGTLLAVQP & NIQ & BV2S1BJ1S6 & CSAR & GG & SYNSPLHFGNGTRLTVT & EDL \\
\hline HD4-91G1 & AV4S1AJ50 & YCI & LRGR & TSYDKVIFGPGTSLSVIP & NIQ & BV7BJ2S2 & CASSQ & GSGGGV & TGELFFGEGSRLTVL & EDL \\
\hline HD4-1C2 & AV4S1AJ50 & YCI & LRGR & TSYDKVIFGPGTSLSVIP & NIQ & $\mathrm{BV} 7 \mathrm{BJ} 2 \mathrm{~S} 2$ & CASSQ & GSGGGV & TGELFFGEGSRLTVL & EDL \\
\hline HD4-94H3 & AV4S1AJ50 & YCI & LRGR & TSYDKVIFGPGTSLSVIP & NIQ & $\mathrm{BV7BJ} 2 \mathrm{~S} 2$ & CASSQ & GSGGGV & TGELFFGEGSRLTVL & EDL \\
\hline MS3-2 & AV4S2A1TAJ27 & YCIVR & PSH & NTNAGKSTFGDGTTLTVKP & NIQ & BV9S2A1PTBJ2S1 & CASS & RGTILG & NEQFFGPGTRLTVL & EDL \\
\hline MS5-2F6 & AV4S2A1TAJ26 & YCIVR & VVD & YGQNFVFGPGTRLSVLP & YIQ & BV2S1BJ2S3 & CSA & KKGTSWK & DTQYFGPGTRLTVL & EDL \\
\hline MS3-1D1 & AV8S2A1N1TAJ16 & FCAE & AQK & GQKLLFARGTMLKVDL & NIQ & BV8S1/2BJ2S7 & CASS & GGSGRG & EQYFGPGTRLTVT & EDL \\
\hline \multirow[t]{2}{*}{ MS1-3B2 } & AV23S1AJ58 & LCA & \multirow[t]{2}{*}{ VRK } & ETSGSRLTFGEGTQLTVNP & DIQ & BV3S1BJ1S7 & CASS & SGSQAA & YEQYFGPGTRLTVT & EDL \\
\hline & & & & & & BV6S5A1N1BJ1S2 & CAS & RSPGS & NYGYTFGSGTRLTVV & EDL \\
\hline HD3-5E9 & AV23S1AJ56 & LCA & $\mathbf{V Y}$ & TGANSKLTFGKGITLSVRP & DIQ & BV2S1BJ1S6 & CAS & RGNRAP & SYEQYFGPGTRLTVT & EDL \\
\hline HD1-14 & AV30S1A1TAJ13 & LCA & VQGA & GGYQKVTFGIGTKLQVIP & NIQ & BV13S3BJ1S2 & CASSE & WAS & GYTFGSGTRLTVV & EDL \\
\hline MS1-3C2 & AV30S1A1TAJ26 & LCA & VQAN & NYGQNFVFGPGTRLSVLP & YIQ & $\mathrm{BV} 7 \mathrm{~S} 2 \mathrm{BJ} 2 \mathrm{~S} 2$ & CASSQ & GPSG & NTGELFFGEGSRLTVL & EDL \\
\hline & & & & & & $\mathrm{BV} 2 \mathrm{~S} 1 \mathrm{BJ} 2 \mathrm{~S} 3$ & CSA & SIGTGA & DTQYFGPGTRLTVL & EDL \\
\hline MS1-4H12 & AV30S1A1TAJ26 & LCA & VQAN & NYGQNFVFGPGTRLSVLP & YIQ & $\mathrm{BV} 7 \mathrm{~S} 2 \mathrm{BJ} 2 \mathrm{~S} 2$ & CASSQ & GPSG & NTGELFFGEGSRLTVL & EDL \\
\hline MS1-5A1 & AV30S1A1TAJ26 & LCA & VQAN & NYGQNFVFGPGTRLSVLP & YIQ & $\mathrm{BV} 7 \mathrm{~S} 2 \mathrm{BJ} 2 \mathrm{~S} 2$ & CASSQ & GPSG & NTGELFFGEGSRLTVL & EDL \\
\hline MS3-1 & AV30S1A1TAJ37§ & LCA & $\mathrm{AY}$ & GSSNTGKLIFGQGTTLQVKP & DIQ & BV20S1A1N1BJ1S1 & CAWS & APGTAY & TEAFFGQGTRLTVV & EDL \\
\hline MS2-1B3 & ND & $T$ & & & & BV2S1BJ2S5 & CSA & KPGTGVG & ETQYFGPGTRLLVL & EDL \\
\hline & & $\alpha 90$ & & & & & & CDR3 & & \\
\hline & & & & & & & $\beta 90$ & & & \\
\hline
\end{tabular}

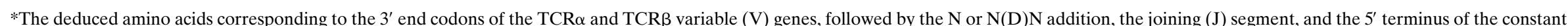

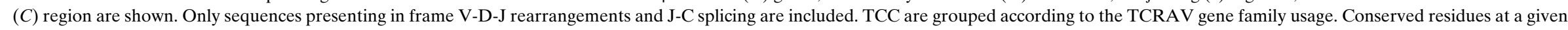

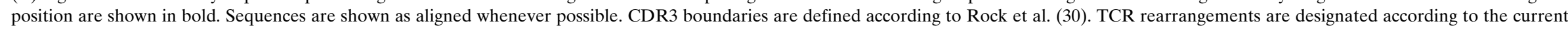
unified nomenclature $(27,31)$. ND, sequence could not be determined. ${ }^{*} \mathrm{Had}$ no $\mathrm{N}$ nucleotide addition. ${ }^{8} \mathrm{~A}$ point mutation of the published TCRAJ sequence was observed. 
communication). In our system, weak binding of MBP(111129) to DRB1*0401 might (a) represent how autoreactive MBP(111-129) specific T cells escape clonal deletion at the central level, and $(b)$ account for the limited heterogeneity observed in the TCR repertoire of cells detectable in the periphery. In fact, a low binding affinity of MBP(111-129) to HLADRB1*0401 would exert a strong bias on the selection of the TCRs capable of binding to the antigen/MHC complex.

Our experimental approach does not allow us to specifically address the influence of either HLA subtype-related differences in antigen processing (71), or individual and epitopespecific variation in processing pathways (72). However, the interpretation we propose is well in line with a recently described differential avidity/affinity model for $\mathrm{T}$ cell selection during thymic development, which defines avidity as the result of interaction of several factors including TCR affinity for peptide/MHC, density of TCR, and density of peptide/MHC complexes (73). High affinity/density of the TCR for intrinsically unstable peptide/MHC complexes (which are therefore likely to be represented at low density on the surface of APCs) might then be responsible for raising the overall avidity to a level sufficient to deliver the signal for positive selection, albeit still below the threshold for clonal deletion. It is conceivable that these interactions might represent the basis of our observations, suggesting an alternate path for $\mathrm{T}$ cell epitopes immunodominance which, to our knowledge, had not been described in a human, autoantigen-specific system. Ongoing efforts in our laboratory aim to extend the presently reported findings with a better understanding of peptide/MHC/TCR interactions and of their role in the pathogenesis and therapeutic immunomodulation of multiple sclerosis.

\section{Acknowledgments}

We thank Drs. H. Kalbacher (Institut für Physiologiche Chemie, Universität Tübingen, Tübingen, Germany), N. Ling (Neurocrine Biosciences, Inc., San Diego, CA), and J. Pascal (Multiple Peptide Systems, San Diego, CA) for providing MBP peptides, and T. Simonis (Dept. of Transfusion Medicine, National Institutes of Health, Bethesda, MD) for donor HLA typing. We are also thankful to Drs. K. Becker, B. Hemmer, M. Pette and U. Utz for helpful suggestions and discussion.

Paolo A. Muraro has been supported by an Italian Multiple Sclerosis Society (AISM) Fellowship. Roland Martin is a Heisenberg fellow of the Deutsche Forschungsgemeinschaft (Ma 965/4-1).

\section{References}

1. Martin, R., H.F. McFarland, and D.E. McFarlin. 1992. Immunological aspects of demyelinating diseases. Annu. Rev. Immunol. 10:153-187.

2. Chou, Y.K., M. Vainiene, R.H. Whitham, D.N. Bourdette, C.H. Chou, G.A. Hashim, H. Offner, and A.A. Vandenbark. 1989. Response of human T lymphocyte lines to myelin basic protein: association of dominant epitopes with HLA class II restriction molecules. J. Neurosci. Res. 23:207-216.

3. Martin, R., D. Jaraquemada, M. Flerlage, J.R. Richert, J.N. Whitaker, E.O. Long, D.E. McFarlin, H.F. McFarland, J. Richert, and J. Whitaker. 1990. Fine specificity and HLA restriction of myelin basic protein-specific cytotoxic $\mathrm{T}$ cell lines from multiple sclerosis patients and healthy individuals. J. Immunol. 145:540-548.

4. Pette, M., K. Fujita, B. Kitze, J.N. Whitaker, E. Albert, L. Kappos, and H. Wekerle. 1990. Myelin basic protein-specific T lymphocyte lines from MS patients and healthy individuals. Neurology. 40:1770-1776.

5. Ota, K., M. Matsui, E.L. Milford, G.A. Mackin, H.L. Weiner, and D.A. Hafler. 1990. T-cell recognition of an immunodominant myelin basic protein epitope in multiple sclerosis. Nature (Lond.). 346:183-187.

6. Richert, J.R., C.A. Reuben-Burnside, G.E. Deibler, and M.W. Kies. 1988. Peptide specificities of myelin basic protein-reactive human T-cell clones.
Neurology. 38:739-742.

7. Richert, J.R., E.D. Robinson, G.E. Deibler, R.E. Martenson, L.J. Dragovic, and M.W. Kies. 1989. Evidence for multiple human T cell recognition sites on myelin basic protein. J. Neuroimmunol. 23:55-66.

8. Chou, Y.K., P. Henderikx, M. Vainiene, R.H. Whitham, D.N. Bourdette, C.H. Chou, G.A. Hashim, H. Offner, and A.A. Vandenbark. 1991. Specificity of human $\mathrm{T}$ cell clones reactive to immunodominant epitopes of myelin basic protein. J. Neurosci. Res. 28:280-290.

9. Hauser, S.L., E. Fleischnick, and H.L. Weiner. 1989. Extended major histocompatibility complex haplotypes in patients with multiple sclerosis. Neurology. 39:275-277.

10. Martin, R., M.D. Howell, D. Jaraquemada, M. Flerlage, J.R. Richert, S.W. Brostoff, E.O. Long, D.E. McFarlin, and H.F. McFarland. 1991. A myelin basic protein peptide is recognized by cytotoxic $\mathrm{T}$ cells in the context of four HLA-DR types associated with multiple sclerosis. J. Exp. Med. 173:19-24.

11. Meinl, E., F. Weber, K. Drexler, C. Morelle, M. Ott, G. SaruhanDireskeneli, N. Goebels, B. Ertl, G. Jechart, and G. Giegerich. 1993. Myelin basic protein-specific $\mathrm{T}$ lymphocyte repertoire in multiple sclerosis. Complexity of the response and dominance of nested epitopes due to recruitment of multiple T cell clones. J. Clin. Invest. 92:2633-2643.

12. Olsson, T., J. Sun, J. Hillert, B. Höjeberg, H.-P. Ekre, G. Andersson, O. Olerup, H. Link, B. Hojeberg, and H.P. Ekre. 1992. Increased numbers of T cells recognizing multiple myelin basic protein epitopes in multiple sclerosis. Eur. J. Immunol. 22:1083-1087.

13. Martin, R., and H.F. McFarland. 1995. Immunological aspects of experimental allergic encephalomyelitis and multiple sclerosis. Crit. Rev. Clin. Lab. Sci. 32:121-182.

14. Brocke, S., K. Gijbels, M. Allegretta, I. Ferber, C. Piercy, T. Blankenstein, R. Martin, U. Utz, N. Karin, and D. Mitchell. 1996. Treatment of experimental encephalomyelitis with a peptide analogue of myelin basic protein. $\mathrm{Na}$ ture (Lond.). 379:343-346.

15. Grasso, M.G., F. Cutrupi, S. Bernardi, S. Trabace, C. Pozzilli, S. Cappellacci, and C. Fieschi. 1992. HLA determinants in familial multiple sclerosis. Neuroepidemiology. 11:85-89.

16. Marrosu, M.G., F. Muntoni, M.R. Murru, G. Spinicci, M.D. Pischedda, F. Goddi, P. Cossu, and M. Pirastu. 1988. Sardinian multiple sclerosis is associated with HLA-DR4: a serologic and molecular analysis. Neurology. 38:1749-1753.

17. Olerup, O., J. Hillert, S. Frederickson, T. Olsson, S. Kam-Hanse, E. Moller, B. Carlsson, and J. Wallin. 1989. Primariliy chronic progressive and relapsing/remitting multiple sclerosis: two immunogenetically distinct disease entities. Proc. Natl. Acad. Sci. USA. 86:7113-7117.

18. Uria, D.F., V. Gutierrez, B.B. Menes, J.M. Arribas, and C. Lopez-Larrea. 1993. HLA class II susceptibility and resistance genes in multiple sclerosis patients from Northern Spain, by DNA-RFLP genotyping. J. Neurol. Neurosurg. Psychiatry. 56:722-723.

19. Bodmer, J.G., S.G. Marsh, E.D. Albert, W.F. Bodmer, R.E. Bontrop, D Charron, B. Dupont, H.A. Erlich, B. Mach, and W.R. Mayr. 1995. Nomenclature for factors of the HLA system, 1995. Eur. J. Immunogenet. 22:335-360.

20. Deibler, G.E., R.E. Martenson, and M.W. Kies. 1972. Large scale preparation of myelin basic protein from central nervous tissue of several mammalian species. Prep. Biochem. 2:139-165.

21. Ling, N., F. Esch, P. Böhlen, P. Brazeau, W.B. Wehrenberg, and R. Guillemin. 1984. Isolation, primary structure, and synthesis of human hypothalamic somatocrinin: growth hormone-releasing factor. Proc. Natl. Acad. Sci. USA. 81:4302-4306.

22. Houghten, R.A. 1985. General method for the rapid solid-phase synthesis of large numbers of peptides: specificity of antigen-antibody interaction at the level of individual amino acids. Proc. Natl. Acad. Sci. USA. 82:5131-5135.

23. Kovats, S., S. Drover, W.H. Marshall, D. Freed, P.E. Whiteley, G.T. Nepom, and J.S. Blum. 1994. Coordinate defects in human histocompatibility leukocyte antigen class II expression and antigen presentation in bare lymphocyte syndrome. J. Exp. Med. 179:2017-2022.

24. Chomczynski, P., and N. Sacchi. 1987. Single-step method of RNA isolation by acid guanidinium thiocyanate-phenol-chloroform extraction. Anal. Biochem. 162:156-159.

25. Utz, U., D. Banks, S. Jacobson, and W.E. Biddison. 1996. Analysis of the T-cell receptor repertoire of human T-cell leukemia virus type 1 (HTLV-1) tax-specific CD8+ cytotoxic T lymphocytes from patients with HTLV-1-associated disease: evidence for oligoclonal expansions. J. Virol. 70:843-851.

26. Genetics Computer Group. 1994. Program manual for the Wisconsin package. Genetics Computer Group, Madison, WI. 754 pp.

27. Arden, B., S.P. Clark, D. Kabelitz, and T.W. Mak. 1995. Human T-cell receptor variable gene segment families. Immunogenetics 42:455-500.

28. Koop, B.F., L. Rowen, K. Wang, K.L. Kuo, D. Seto, J.A. Lenstra, S Howard, W. Shan, P. Desphande, and L. Hood. 1994. The human T-cell receptor TCRAC/TCRDC $(\mathrm{Ca} / \mathrm{Cd})$ region: organization, sequence, and evolution of $97.6 \mathrm{~kb}$ of DNA. Genomics. 19:478-493.

29. Toyonaga, B., Y. Yoshikai, V. Vadasz, B. Chin, and T.W. Mak. 1985. Organization and sequences of the diversity, joining and constant region genes of the human T-cell receptor b chain. Proc. Natl. Acad. Sci. USA. 82:8624-8628.

30. Rock, E.P., P.R. Sibbald, M.M. Davis, and W. Chien. 1994. CDR3 Length in antigen-specific immune receptors. J. Exp. Med. 179:323-328. 
31. WHO-IUIS Nomenclature Sub-Committee on TCR Designation. 1995. Nomenclature for T-cell receptor (TCR) gene segments of the immune system. Immunogenetics. 42:451-453.

32. Kropshofer, H., I. Bohlinger, H. Max, and H. Kalbacher. 1991. Self and foreign peptides interact with intact and disassembled MHC class II antigen HLA-DR via Trp pockets. Biochemistry. 30:9177-9187.

33. Kropshofer, H., H. Max, T. Halder, M. Kalbus, C.A. Müller, and H. Kalbacher. 1993. Self-peptides from four HLA-DR alleles share hydrophobic anchor residues near the $\mathrm{N}$ terminus including proline as a stop-signal for trimming. J. Immunol. 151:4732-4742.

34. Kono, D.H. 1993. Experimental allergic encephalomyelitis. In The Molecular Pathology of Autoimmune Diseases. C.A. Bona, K.A. Siminovich, M. Zanetti, and A.N. Thofilopoulos, editors. Harwood Academic Publishers, Chur, Switzerland. 585-600.

35. Hammer, J., F. Galazzi, E. Bono, R.W. Karr, J. Guenot, P. Valsasnini, Z. Nagy, and F. Sinigaglia. 1995. Peptide binding specificity of HLA-DR4 molecules: correlation with rheumatoid arthritis association. J. Exp. Med. 181:18471855.

36. Moss, P.A., W.M. Rosemberg, E. Zintzaras, and J.I. Bell. 1993. Characterization of the human $\mathrm{T}$ cell receptor a-chain repertoire and demonstration of a genetic influence on Va usage. Eur. J. Immunol. 23:1153-1559.

37. Hall, M.A., and J.S. Lanchbury. 1995. Healthy human T-cell receptor beta-chain repertoire: quantitative analysis and evidence for J-beta-related effects on CDR3 structure and diversity. Hum. Immunol. 43:207-218.

38. Nepom, G.T., and H.A. Erlich. 1991. MHC class-II molecules and autoimmunity. Annu. Rev. Immunol. 9:493-525.

39. Bernard, C.C. 1973. Experimental autoimmune encephalomyelitis in mice: genetic control of susceptibility. J. Immunogenetics. 3:263-274.

40. Gasser, D.L., C.M. Newlin, J. Palm, and N.K. Gonatas. 1973. Genetic control of susceptibility to experimental allergic encephalomyelitis in rats. Science (Wash. DC). 181:872-873.

41. Ben-Nun, A., H. Otmy, and I.R. Cohen. 1981. Genetic control of autoimmune encephalomyelitis and recognition of the critical nonapeptide moiety of myelin basic protein in guinea pigs are exerted through interaction of lymphocytes and macrophages. Eur. J. Immunol. 11:311-316.

42. Steinman, L. 1992. Multiple sclerosis and its animal models: the role of the major histocompatibility complex and the $\mathrm{T}$ cell receptor repertoire. Springer Semin. Immunopathol. 14:79-93.

43. Ben-Nun, A., R.S. Liblau, L. Cohen, D. Lehmann, E. TournierLasserve, A. Rosenzweig, J. Zhang, J.C. Raus, and M.A. Bach. 1991. Restricted $\mathrm{T}$-cell receptor $\mathrm{V}$ beta gene usage by myelin basic protein-specific $\mathrm{T}$-cell clones in multiple sclerosis: predominant genes vary in individuals. Proc. Natl. Acad. Sci. USA. 88:2466-2470.

44. Giegerich, G., M. Pette, E. Meinl, J.T. Epplen, H. Wekerle, and A. Hinkkanen. 1992. Diversity of T cell receptor alpha and beta chain genes expressed by human $\mathrm{T}$ cells specific for similar myelin basic protein peptide/major histocompatibility complexes. Eur. J. Immunol. 22:753-758.

45. Hafler, D.A., M.G. Saadeh, V.K. Kuchroo, E.L. Milford, and L. Steinman. 1996. T cell receptor usage in human and experimental demyelinating diseases. Immunol. Today. 17:152-159.

46. Zhang, J., R. Medaer, G.A. Hashim, Y. Chin, E. van den Berg-Loonen, and J.C. Raus. 1992. Myelin basic protein-specific T lymphocytes in multiple sclerosis and controls: precursor frequency, fine specificity, and cytotoxicity. Ann. Neurol. 32:330-338.

47. Wucherpfennig, K.W., A. Sette, S. Southwood, C. Oseroff, M. Matsui, J.L. Strominger, and D.A. Hafler. 1994. Structural requirements for binding of an immunodominant myelin basic protein peptide to DR2 isotypes and for its recognition by human T cell clones. J. Exp. Med. 179:279-290.

48. Martin, R., R.R. Voskuhl, M. Flerlage, D.E. McFarlin, H.F. McFarland, and R. Voskuhl. 1993. Myelin basic protein-specific T-cell responses in identical twins discordant or concordant for multiple sclerosis. Ann. Neurol. 34:524-535.

49. Utz, U., W.E. Biddison, H.F. McFarland, D.E. McFarlin, M. Flerlage, and R. Martin. 1993. Skewed T-cell receptor repertoire in genetically identical twins correlates with multiple sclerosis. Nature (Lond.). 364:243-247.

50. Voskuhl, R.R., R. Martin, and H.F. McFarland. 1993. A functional basis for the association of HLA class II genes and susceptibility to multiple sclerosis: cellular immune responses to myelin basic protein in a multiplex family. J. Neuroimmunol. 42:199-208.

51. Hawes, G.E., L. Struyk, B.C. Godthelp, and P.J. van den Elsen. 1995. Limited restriction in the TCR-ab V region usage of antigen-specific clones recognition of myelin basic protein (amino acids 84-102) and mycobacterium bovis $65-\mathrm{kD}$ heat shock protein (amino acids $3-13$ ) by $\mathrm{T}$ cell clones established from peripheral blood mononuclear cells of monozygotic twins and HLA-identical individuals. J. Immunol. 154:555-566.

52. Victoria-Gutierrez, M., E. Martinez-Naves, E. Coto, O. Dominguez, F. Uria, J.M. Urra, and C. Lopez-Larrea. 1991. DNA analysis of HLA-DR4B1 subtypes in multiple sclerosis by specific oligonucleotide probes. J. Neuroimmunol. 32:279-283.

53. Tait, B.D., B.P. Drummond, M.D. Varney, and L.C. Harrison. 1995 HLA-DRB $1 * 0401$ is associated with susceptibility to insulin-dependent diabetes mellitus independently of the DQB1 locus. Eur. J. Immunogenet. 22:289-297.

54. Sanjeevi, C.B., P. Höök, M. Landin-Olsson, I. Kockum, G. Dahlquist, T.P. Lybrand, and Å. Lernmark. 1996. DR4 subtypes and their molecular properties in a population-based study of Swedish childhood diabetes. Tissue Antigens. 47:275-283.

55. Tighe, H.P., G.J. Silverman, and D.A. Carson. 1993. Rheumatoid arthritis. In The Molecular Pathology of Autoimmune Diseases. C.A. Bona, K.A Siminovich, M. Zanetti, and A.N. Thofilopoulos, editors. Harwood Academic Publishers, Chur, Switzerland. 347-362.

56. Dong, R.P., A. Kimura, H. Hashimoto, M. Akizuki, Y. Nishimura, and T. Sasazuki. 1993. Difference in HLA-linked genetic background between mixed connective tissue disease and systemic lupus erythematosus. Tissue Antigens. 41:20-25.

57. Olsson, T., W.W. Zhi, B. Hojeberg, V. Kostulas, Y.P. Jiang, G. Anderson, H.P. Ekre, and H. Link. 1990. Autoreactive T lymphocytes in multiple sclerosis determined by antigen-induced secretion of interferon-gamma. J. Clin. Invest. 86:981-985.

58. Westall, F.C., A.B. Robinson, J. Caccam, J. Jackson, and E.H. Eylar. 1971. Essential chemical requirements for induction of allergic encephalomyelitis. Nature (Lond.). 229:22-24.

59. Teitelbaum, D., C. Webb, R. Arnon, and M. Sela. 1977. Strain differences in susceptibility to experimental allergic encephalomyelitis and the immune response to the encephalitogenic determinant in inbred guinea pigs. Cell Immunol. 29:265-271.

60. Hashim, G., A.A. Vandenbark, D.P. Gold, T. Diamanduros, and H. Offner. 1991. T cell lines specific for an immunodominant epitope of human basic protein define an encephalitogenic determinant for experimental autoimmune encephalomyelitis-resistant Lou/M rats. J. Immunol. 146:515-520.

61. Salvetti, M., G. Ristori, M. D'Amato, C. Buttinelli, M. Falcone, C. Fieschi, H. Wekerle, and C. Pozzilli. 1993. Predominant and stable T cell responses to regions of myelin basic protein can be detected in individual patients with multiple sclerosis. Eur. J. Immunol. 23:1232-1239.

62. Vandevyver, C., N. Mertens, P. van den Elsen, R. Medaer, J. Raus, and J. Zhang. 1995. Clonal expansion of myelin basic protein-reactive T cells in patients with multiple sclerosis: restricted $\mathrm{T}$ cell receptor $\mathrm{V}$ gene rearrangements and CDR3 sequence. Eur. J. Immunol. 25:958-968.

63. Fairchild, P.J., R. Wildgoose, E. Atherton, S. Webb, and D.C. Wraith. 1993. An autoantigenic T cell epitope forms unstable complexes with class II MHC: a novel route for escape from tolerance induction. Int. Immunol. 5:11511158 .

64. Mason, K., and H.M. McConnell. 1994. Short-lived complexes between myelin basic protein peptides and IA ${ }^{\mathrm{k}}$. Proc. Natl. Acad. Sci. USA. 91:1246312466

65. Mason, K., D.W. Denney, and H.M. McConnell. 1995. Myelin basic protein complexes with the class II MHC molecules I- $\mathrm{A}^{\mathrm{u}}$ and $\mathrm{I}-\mathrm{A}^{\mathrm{k}}$ form and dissociate rapidly at neutral pH. J. Immunol. 154:5216-5227.

66. Joosten, I., M.H. Wauben, M.C. Holewijn, K. Reske, L.O. Pedersen, C.F. Rosenboom, E.J. Hensenm, W. van Eden, and S. Buus. 1994. Direct binding of autoimmune disease related $\mathrm{T}$ cell epitopes to purified Lewis rat MHC class II molecules. Int. Immunol. 6:751-759.

67. Liu, G.Y., P.J. Fairchild, R.M. Smith, J.R. Prowle, D. Kioussis, and D.C Wraith. 1995. Low avidity recognition of self-antigen by $\mathrm{T}$ cells permits escape from central tolerance. Immunity. 3:407-415.

68. Heber-Katz, E., and H. Acha-Orbea. 1989. The V-region disease hypothesis: evidence from autoimmune encephalomyelitis. Immunol. Today. 10: 164-169.

69. Martin, R., U. Utz, J.E. Coligan, J.R. Richert, M. Flerlage, E. Robinson, R. Stone, W.E. Biddison, D.E. McFarlin, and H.F. McFarland. 1992. Diversity in fine specificity and $\mathrm{T}$ cell receptor usage of the human CD4+ cytotoxic T cell response specific for the immunodominant myelin basic protein peptide $87-$ 106. J. Immunol. 148:1359-1366.

70. Martin, R., and H.F. McFarland. 1992. T cell receptor usage in neurological disease: the case in multiple sclerosis. Semin. Neurosci. 4:243-248.

71. Nicolle, M.W., S. Hawke, N. Willcox, and A. Vincent. 1995. Differences in processing of an autoantigen by DR4:Dw4.2 and DR4: Dw14.2 antigen-presenting cells. Eur. J. Immunol. 25:2119-2122.

72. Demotz, S., P.M. Matricardi, D. Irle, P. Panina, A. Lanzavecchia, and G. Corradin. 1989. Processing of tetanus toxin by human antigen-presenting cells: evidence for donor and epitope-specific processing pathways. J. Immunol. 143: 3881-3886.

73. Ashton-Rickardt, P.G., and S. Tonegawa. 1994. A differential-avidity model for T-cell selection. Immunol. Today. 15:362-366. 